\title{
Sodium Butyrate Alters Cell-Cell Interactions through Up-Regulation of E-Cadherin in Human Hepatocellular Carcinoma Cells
}

\author{
Hyun Jin Kwun and Kyung Lib Jang* \\ Department of Microbiology, College of Natural Sciences, Pusan National University, Busan 609-735, South Korea
}

Received March 10, 2009 /Accepted March 17, 2009

\begin{abstract}
Sodium butyrate $(\mathrm{NaBt})$, a naturally occurring short chain fatty acid derived from carbohydrate metabolism in the gut, is known to exhibit strong anti-cancer potentials in various human cancer cells; however, its action mechanism is poorly understood. In the present study, we demonstrated that $\mathrm{NaBt}$ up-regulates levels of E-cadherin, a key cell adhesion molecule implicated as a tumor suppressor, in a cell type-specific manner. Although levels of p21, a potential activator for E-cadherin expression, were also up-regulated by treatment with $\mathrm{NaBt}$ in several types of cells, it does not seem to be associated with the activation of E-cadherin in the NaBt-treated cells. Instead, the data from promoter analysis suggest that $\mathrm{NaBt}$ up-regulates expression of E-cadherin at the transcription level by enhancing its promoter strength via a CCAAT-box. The elevated E-cadherin in the presence of NaBt was primarily localized at the cell-cell contacts, converting Hep3B cells into a more differentiated form.
\end{abstract}

Key words : CCAAT-box, CTF, E-cadherin, hepatocellular carcinoma, sodium butyrate

\section{Introduction}

E-cadherin has been shown to execute important functions in embryogenesis and tissue architecture by forming intercellular junction complexes and establishing cell polarization [28]. In addition, E-cadherin is a subject of intense interest in cancer research. Especially, loss of E-cadherin expression has been closely correlated with tumor invasiveness [15]. It is frequently suppressed or reduced in carcinoma tissues of the breast and liver, and many carcinoma cell lines derived from colon, stomach, and prostate [20]. Introduction of E-cadherin into tumor cells can reduce invasiveness, an effect that can be blocked by anti-E-cadherin antibodies [23]. Consequently, knowledge of the molecular mechanism that controls its expression or function is of primary importance in understanding the process of tumor invasion.

Sodium butyrate $(\mathrm{NaBt})$, a naturally occurring short chain fatty acid resulting from carbohydrate metabolism in the gut, is known to arrest cell growth and to induce differentiation in various cell types $[9,26]$. NaBt is known to induce cell cycle arrest by activating the expression of p21, a potent inhibitor of cyclin-dependent kinases (CKI) [22]. However, the mechanism by which $\mathrm{NaBt}$ induces differentiation is poorly understood. In the present study, we

\footnotetext{
${ }^{*}$ Corresponding author

Tel : +82-51-510-2178, Fax : +82-51-514-1778

E-mail : kljang@pusan.ac.kr
}

show that NaBt up-regulates levels of E-cadherin, a key cell adhesion molecule implicated as a tumor suppressor, in a cell type-specific manner. In addition, we investigate the mechanism by which $\mathrm{NaBt}$ up-regulates E-cadherin expression in human hepatocellular carcinoma cells (HCC). Considering the importance of E-cadherin in the maintenance of cell shape and cell-cell adhesion, the effect must be important for the morphological change during differentiation induced by $\mathrm{NaBt}$.

\section{Materials and Methods}

\section{Plasmids}

The E-cadherin promoter (GenBank accession No. AY341818) was obtained from genomic DNA of HepG2 cells by PCR amplification using a primer pair, Ecad forward (5'-ACC GCT CGA GCC CAG GAG TT-3', -453 to -433 ) and Ecad reverse (5'-CCG CAA GCT TAC AGG TGG T-3', +34 to +15$)$. The E-cadherin promoter from -448 to +29 was subcloned into the Xho I and Hind III sites of the luciferase reporter vector, pGL2-basic (Promega) to create Ecad 448 . The fragment from -70 to +29 was amplified using a primer set, E-box 2 (5'-GCA GAG GTA CCC TCA GCC AAT CA-3', -76 to -53 ) and Ecad reverse and was cloned into the Kpn I and Hind III sites of the luciferase vector to generate Ecad-70. For Ecad -60 , the fragment from -60 to +29 was amplified using a primer set, CAAT (5'-AGC CAG CTA GCG GTA CGG GGG GC-3', -66 to -43 ) and Ecad reverse, and was cloned 
into the Nhe I and Hind III sites of the luciferase vector. For Ecad $_{21}$, the fragment from -448 to -22 in Ecad $_{448}$ was deleted using the $P_{s t}$ I site located at -21 . Ecad ${ }_{\triangle \mathrm{CAAT}}$ that has nucleotide substitutions to destruct the CCAAT box (5'-GCC AAT-3' to $5^{\prime}$-GCT AGC-3') was constructed by PCR-directed

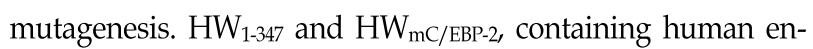
dogenous virus type $W$ (HERV-W) long terminal repeat (LTR) in an intact and a CCAAT box-defective forms, respectively, were described previously [18]. Both TK and

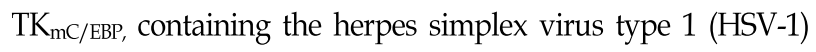
thymidine kinase (TK) promoter were also described previously [17].

\section{Transfection and luciferase assay}

Human epithelial cell lines, HCC HepG2 (KCLB 58065) and Hep3B (KCLB 58064), breast carcinoma MCF-7 (ATCC HTB-22) were obtained from the American Type Culture Collection (ATCC) whereas MDA-MB-231 (KCLB 30026), cervical carcinoma HeLa (KCLB 30022), embryonal kidney HEK 293 (ATCC CRL-1573), and colon carcinoma HCT 116 (KCLB 10002) were from Korean Cell Line Bank (KCLB). Cells were seeded at $2 \times 10^{5}$ cells per $60-\mathrm{mm}$ diameter plate and transfected the next day with the use of the WelFect-EX ${ }^{\mathrm{TM}}$ PLUS (WelGENE) following the manufacturer's instruction. To control for variation in transfection efficiency, $1 \mu \mathrm{g}$ of plasmid pCH110 (Pharmacia) containing the $E$. coli lac $Z$ gene under control of the SV40 promoter was cotransfected. When appropriate, cells were treated with either NaBt (Sigma) or cisplatin (Sigma) at the indicated concentration for $24 \mathrm{hr}$. At $48 \mathrm{hr}$ after transfection, the level of expression from the target gene (luciferase activity) was analyzed and values obtained were normalized to the $\beta$ -galactosidase activity measured in the corresponding cell extracts. Each experiment was repeated at least three times.

\section{Western blot analysis}

Cells were lysed in buffer (50 mM Tris-HCl, pH 8, 150 $\mathrm{mM} \mathrm{NaCl}, 0.1 \% \mathrm{SDS}, 1 \% \mathrm{NP}-40$ ) supplemented with protease inhibitors. $10 \mu \mathrm{g}$ of cell extracts was separated by SDS-PAGE and transferred onto a nitrocellulose membrane (Hybond PVDF; Amersham). Western blotting was performed with either anti-p53 monoclonal antibody (Santa Cruz), anti-p21 rabbit polyclonal IgG (Santa Cruz), anti-E-cadherin monoclonal antibody (Calbiochem), anti- $\beta$ -catenin monoclonal antibody (BD Transduction Laboratories) or anti-actin monoclonal IgG (Santa Cruz), and subsequently detected by chemiluminescent ECL kit (Amesham) as recommended by the manufacturer.

\section{Immunofluorescence}

For indirect immunofluorescence, the cells were fixed and permeabilized with 95\% methanol in phosphate-buffered saline at $-20^{\circ} \mathrm{C}$ for $10 \mathrm{~min}$. Cells were then reacted with 1:100 dilution of a mouse anti-E-cadherin monoclonal antibody (Calbiochem), followed by 1:80 dilution of anti-mouse immunoglobulin-fluorescein (Chemicon International). The cells were photographed on a Carl Zeiss microscope equipped for fluorescent illumination at a magnification of $\times 400$ with Kodak Gold 400 film.

\section{Results and Discussion}

First, we investigated the effect of $\mathrm{NaBt}$ on the expression of E-cadherin in a human hepatoma cell line, HepG2. As a result, both RNA and protein levels of E-cadherin were up-regulated by $\mathrm{NaBt}$ in a dose-dependent manner (Fig. 1A and $1 \mathrm{~B})$. To assess whether the effect is common in human epithelial cells, we employed six additional cell lines of
A

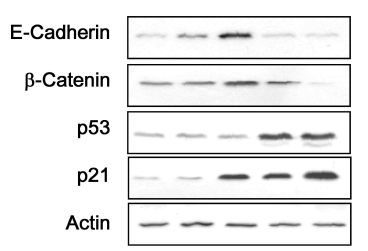

$\mathrm{NaBt}(\mathrm{mM}) \quad 0 \quad 0.5 \quad 5 \quad 000$

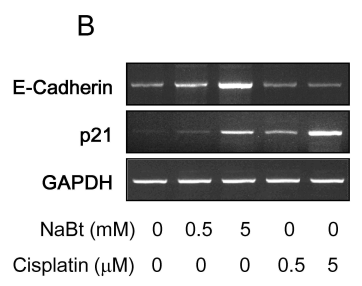

Cisplatin $(\mu \mathrm{M}) \quad 0 \quad 0 \quad 00.5 \quad 5$

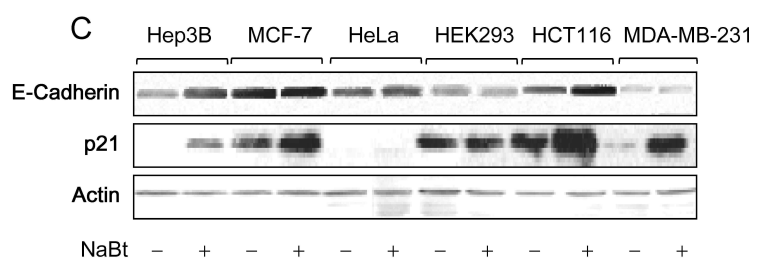

Fig. 1. p21-independent activation of E-cadherin expression by NaBt. A: HepG2 cells were treated with either $\mathrm{NaBt}$ (lanes 2 and 3) or cisplatin (lanes 4 and 5) for $24 \mathrm{hr}$ at the indicated concentration. Levels of E-cadherin, $\beta$ -catenin, p53, p21, and Actin were measured by Western blots. B: Levels of E-cadherin, p21, and GAPDH RNA transcaripts in HepG2 cells prepared as in Fig. 1A were determined by RT-PCR. C: Protein levels of E-cadherin, p21, and Actin in Hep3B, MCF-7, HeLa, HEK298, HCT116, MDA-MB-231 cells with or without NaBt treatment $(5 \mathrm{mM})$ were determined by Western blots. 
Hep3B, HCT116, and MCF7 cells while it was not responsive to cisplatin treatment (Fig. $2 \mathrm{~A}$ and $2 \mathrm{~B}$ ). Taken together, we conclude that p21 is not involved in the NaBt-mediated activation of E-cadherin expression.

To provide a mechanism by which $\mathrm{NaBt}$ activates E-cadherin transcription, we tried to define a NaBt-response element(s) in the E-cadherin promoter. For this purpose, we cloned E-cadherin promoter composed of approximately 400 bp upstream of the human E-cadherin transcription site $[4,11]$ from human genomic DNA isolated from HepG2 cells. The E-cadherin promoter is known to contain several positive regulatory elements including a CCAAT box and a Sp1 binding site (GC box) as well as two E-boxes (CANNTG) to which a repressor role is ascribed (Fig. 2C) [11,19]. To get insight into what might be involved in the NaBt-mediated activation of the E-cadherin promoter, we analyzed the activity of serial $5^{\prime}$ deletion constructs of the promoter (Fig. $2 \mathrm{C}$ ). Deletion of the fragment spanning -448 to -71 reduced the basal promoter activity up to $50 \%$ of the full-length promoter, suggesting the presence of a positive regulatory element(s) in addition to the negative regulatory E-box 2 in the deleted region $[11,19]$. However, the activation fold by $\mathrm{NaBt}$ was little affected by the deletion. Further deletion up to -61 as in Ecad-60 resulted in not only additional reduction in basal activity but also almost complete abolishment of the promoter activation by $\mathrm{NaBt}$, both of which possibly resulted from removal of the positive regulatory CCAAT box located at -65 to -61 . Consistently, Ecad ${ }_{\triangle \mathrm{CAAT}}$ that contains a mutated CCAAT box by nucleotide substitutions was not responsive to $\mathrm{NaBt}$ treatment (Fig. $2 \mathrm{C}$ ), indicating that the CCAAT box plays a role in the activation of E-cadherin by NaBt.

To provide additional evidence that $\mathrm{NaBt}$ activates transcription of E-cadherin via the CCAAT box, we employed other CCAAT box-containing promoters and tested their response to $\mathrm{NaBt}$. According to our previous reports, a functional CCAAT box is critical for the promoter activity in both HERV-W LTR and HSV-1 TK promoter $[17,18]$. Both promoters were activated in HepG2 cells by treatment with $\mathrm{NaBt}$, approximately 4 and 6 folds, respectively (Fig. 2D). However, neither of the two promoters containing a defective CCAAT box was responsive to NaBt. Therefore, we concluded that $\mathrm{NaBt}$ activates expression of the E-cadherin gene via the CCAAT box probably by stimulating the CCAAT-box binding transcription factor (CTF).

To explain the cell type-specific activation of E-cadherin
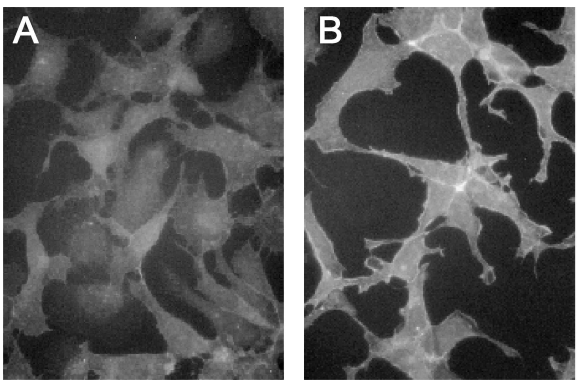

Fig. 3. Morphological alteration of hepatocellular carcinoma cells by treatment with NaBt. Hep3B cells were either mocktreated (A) or treated (B) with $5 \mathrm{mM} \mathrm{NaBt}$ for $24 \mathrm{hr}$. Indirect immunoflorescence assay was performed to locate E-cadherin in cells before and after $\mathrm{NaBt}$ treatment.

by $\mathrm{NaBt}$, we tested the promoter activity of E-cadherin in various cell lines in the absence or presence of $\mathrm{NaBt}$. Consistently to the results shown in Fig. 2A, the E-cadherin promoter in Ecad-448 was successfully activated by $\mathrm{NaBt}$ in Hep3B, HCT 116 and breast carcinoma MCF-7 cells whereas the promoter in E-cad-80 was not (Fig. 2B). A similar level of E-cadherin promoter activation by $\mathrm{NaBt}$ was also observed in other cell lines such as human embryonal kidney HEK 293 and breast carcinoma MDA-MB-231 cells (data not shown). Therefore, the cell type-specific up-regulation of E-cadherin by $\mathrm{NaBt}$ might not result from the differential activation of CCAAT box by $\mathrm{NaBt}$. Instead, it might reflect the difference in the mechanism of down-regulation of E-cadherin in various carcinoma cells. The inactivation of E-cadherin promoter in carcinoma cells seems to occur through different mechanisms such as hypermethylation of CpG sites [12,29], the presence of two E-boxes [11], loss of activating protein-2 (AP-2) expression [2,14], up-regulation of transcription repressor Snail [1,24], and a single nucleotide polymorphism in the E-cadherin promoter [16]. Therefore, the elevated CTF activity by $\mathrm{NaBt}$ might be not sufficient to activate the E-cadherin promoter in some cell lines that contain dominating mechanism for its expression.

Finally, we investigated the morphological changes of hepatoma cells following induction of E-cadherin upon $\mathrm{NaBt}$ treatment. Hep3B cells tend to proliferate individually, exhibiting extremely rare cell-cell interactions (Fig. 3A). Following NaBt treatment, Hep3B cells contact each other, resembling HepG2 in growth pattern (Fig. 3B). The indirect immunofluorescence data show that the elevated E-cadherin in the presence of $\mathrm{NaBt}$ primarily localizes at the cell-cell contact faces, inducing the carcinoma cells into more differentiated form. 
More extensive studies are required to understand the exact mechanism of the NaBt-mediated E-cadherin activation. In particular, it is necessary to reveal the pathway through which NaBt stimulates CTF activity, leading to the subsequent induction of E-cadherin transcription. The CTF transcription factors are known to regulate gene expression initiated through a number of signal transduction pathways, including those controlled by insulin [7], TGF- $\beta$ [27], c-AMP [8], steroid hormones [5] and others. In most cases, only a single pathway-specific gene has been studied, making generalization impossible. Since the expression of CTF proteins can be affected by the growth and differentiation state of cells [16], it is difficult whether the effects of agents on CTF proteins are direct or indirect. In addition, although posttranslational modifications such as phosphorylation [6] and O-glycosylation [13] of CTF-proteins were demonstrated, yet it is still unclear whether these modifications affect CTF function in vivo. To resolve these issues, it is necessary to determine the specific member of CTF family present in the cells and demonstrate the specific biochemical pathways by which NaBt affects its expression or modification. Nonetheless, the present study shows that NaBt induces up-regulation of E-cadherin and consequent morphological changes, which might contribute to the anti-cancer activity of $\mathrm{NaBt}$.

\section{Acknowledgement}

This work was supported for two years by Pusan National University Research Grant.

\section{References}

1. Batlle, E., E. Sancho, C. Franci, D. Dominguez, M. Monfar, J. Baulida, and A. Garcia De Herreros. 2000. The transcription factor snail is a repressor of E-cadherin gene expression in epithelial tumour cells. Nat. Cell Biol. 2, 84-89.

2. Batsche, E., C. Muchardt, J. Behrens, H. C. Hurst, and C. Cremisi. 1998. RB and c-Myc activate expression of the E-cadherin gene in epithelial cells through interaction with transcription factor AP-2. Mol. Cell Biol. 18, 3647-3658.

3. Bukholm, I. K., J. M. Nesland, R. Kåresen, U. Jacobsen, and A. L. Børresen-Dale. 1997. Expression of E-cadherin and its relation to the p53 protein status in human breast carcinomas. Virchows Arch 431, 317-321.

4. Bussemakers, M. J., L. A. Giroldi, A. van Bokhoven, and J. A. Schalken. 1994. Transcriptional regulation of the human E-cadherin gene in human prostate cancer cell lines: characterization of the human E-cadherin gene promoter.
Biochem Biophys. Res. Commun. 203, 1284-1290.

5. Chaudhry, A. Z., A. D. Vitullo, and R. M. Gronostajski. 1999. Nuclear factor I-mediated repression of the mouse mammary tumor virus promoter is abrogated by the coactivators p300/CBP and SRC-1. J. Biol. Chem 274, 7072-7081.

6. Coke, D. W. and M. D. Lane. 1988. A sequence element in the GLUT4 gene that mediates repression by insulin. J. Biol. Chem 273, 6210-6217.

7. Cooke, D. W. and M. D. Lane. 1999. The transcription factor nuclear factor I mediates repression of the GLUT4 promoter by insulin. J. Biol. Chem 274, 12917-12924.

8. Cooke, D. W. and M. D. Lane. 1999. Transcription factor NF1 mediates repression of the GLUT4 promoter by cyclic-AMP. Biochem Biophys. Res. Commun. 260, 600-604.

9. Couchie, D., N. Holic, M. N. Chobert, A. Corlu, and Y. Laperche. 2002. In vitro differentiation of WB-F344 rat liver epithelial cells into the biliary lineage. Differentiation 69, 209-215.

10. Eastman, A. 1990. Activation of programmed cell death by anticancer agents: cisplatin as a model system. Cancer Cells 2, 275-280.

11. Giroldi, L. A., P. P. Bringuier, M. de Weijert, C. Jansen, A. van Bokhoven, and J. A. Schalken. 1997. Role of E boxes in the repression of E-cadherin expression. Biochem Biophys. Res. Commun. 241, 453-458.

12. Graff, J. R., J. G. Herman, R. G. Lapidus, H. Chopra, R. Xu, D. F. Jarrard, W. B. Isaacs, P. M. Pitha, N. E. Davidson, and S. B. Baylin. 1995. E-cadherin expression is silenced by DNA hypermethylation in human breast and prostate carcinomas. Cancer Res. 55, 5195-5199.

13. Jackson, S. P. and R. Tjian. 1988. O-glycosylation of eukaryotic transcription factors: implications for mechanisms of transcriptional regulation. Cell 55, 125-133.

14. Jean, D., J. E. Gershenwald, S. Huang, M. Luca, M. J. Hudson, M. A. Tainsky, and M. Bar-Eli. 1998. Loss of AP-2 results in up-regulation of MCAM/MUC18 and an increase in tumor growth and metastasis of human melanoma cells. J. Biol. Chem 273, 16501-16508.

15. Jeanes, A. and C. J. Gottardi, and A. S. Yap. 2008. Cadherins and cancer: how does cadherin dysfunction promote tumor progression? Oncogene 27, 6920-6929.

16. Kulkarni, S. and R. M. Gronostajski. 1996. Altered expression of the developmentally regulated NFI gene family during phorbol ester-induced differentiation of human leukemic cells. Cell Growth Differ. 7, 501-510.

17. Kwun, H. J., S. W. Yim, D. H. Lee, and K. L. Jang. 1997. Activation of the thymidine kinase promoter by herpes simplex virus type 1 immediate early proteins. Mol. Cells 9 , 277-280.

18. Lee, W. J., H. J. Kwun, H. S. Kim, and K. L. Jang. 2003. Activation of the human endogenous retrovirus $\mathrm{W}$ long terminal repeat by herpes simplex virus type 1 immediate early protein 1. Mol. Cells 15, 75-80.

19. Li, L. C., R. M. Chui, M. Sasaki, K. Nakajima, G. Perinchery, H. C. Au, D. Nojima, P. Carroll, and R. Dahiya. 2000. A 
single nucleotide polymorphism in the E-cadherin gene promoter alters transcriptional activities. Cancer Res. 60, 873-876.

20. Momparler, R. L. and V. Bovenzi. 2000. DNA methylation and cancer. J. Cell Physiol. 183, 145-154.

21. Mueller, S., E. Cadenas, and A. H. Schönthal. 2000. p21WAF1 regulates anchorage-independent growth of HCT116 colon carcinoma cells via E-cadherin expression. Cancer Res. 60, 156-163.

22. Nakano, K., T. Mizuno, Y. Sowa, T. Orita, T. Yoshino, Y. Okuyama, T. Fujita, N. Ohtani-Fujita, Y. Matsukawa, T. Tokino, H. Yamagishi, T. Oka, H. Nomura, and T. Sakai. 1997. Butyrate activates the WAF1/Cip1 gene promoter through Sp1 sites in a p53-negative human colon cancer cell line. J. Biol. Chem 272, 22199-22206.

23. Perl, A. K., P. Wilgenbus, U. Dahl, H. Semb, and G. Christofori. 1998. A causal role for E-cadherin in the transition from adenoma to carcinoma. Nature 392, 190-193.

24. Poser, I., D. Dominguez, A. G. de Herreros, A. Varnai, R. Buettner, and A. K. Bosserhoff. 2001. Loss of E-cadherin ex- pression in melanoma cells involves up-regulation of the transcriptional repressor Snail. J. Biol. Chem 276, 2466124666.

25. Sadot, E., B. Geiger, M. Oren, and A. Ben-Ze'ev. Down-regulation of beta-catenin by activated p53. Mol. Cell Biol. 21, 6768-6781.

26. Saito, H., H. Ebinuma, M. Takahashi, F. Kaneko, K. Wakabayashi, M. Nakamura, and H. Ishii. 1998. Loss of butyrate-induced apoptosis in human hepatoma cell lines HCC-M and HCC-T having substantial Bcl-2 expression. Hepatology 27, 1233-1240.

27. Sun, P., P. Dong, K. Dai, G. J. Hannon, and D. Beach. 1998. p53-independent role of MDM2 in TGF-beta1 resistance. Science 282, 2270-2272.

28. van Roy, F. and G. Berx. 2008. The cell-cell adhesion molecule E-cadherin. Cell Mol. Life Sci. 65, 3756-3788.

29. Yoshiura, K., Y. Kanai, A. Ochiai, Y. Shimoyama, T. Sugimura, and S. Hirohashi. 1995. Silencing of the E-cadherin invasion-suppressor gene by CpG methylation in human carcinomas. Proc. Natl. Acad Sci. USA 92, 7416-7419.

\section{초록 : Sodium butyrate에 의한 E-cadherin의 발현증가와 세포간 상호작용의 변화}

\section{권현진 · 장경립*}

(부산대학교 자연과학대학 미생물학과)

Sodium butyrate $(\mathrm{NaBt})$ 는 장에서 탄수화물대사로부터 생겨나는 짧은 천연지방산 사슬로 다양한 인간 암세포들 에게서 강력한 항암효능을 나타냄이 보고된 바 있지만 자세한 기전은 아직 알려져 있지 않다. 이 논문에서 우리는 $\mathrm{NaBt}$ 가 주요 세포부착분자이면서 종양억제인자의 일종인 E-cadherin의 발현을 세포-특이적으로 촉진하는 기전을 연구하였다. 또한 NaBt는 E-cadherin의 발현을 촉진하는 것으로 알려진 p21의 발현도 증가시켰지만, NaBt에 의하여 증가한 p21은 E-cadherin의 활성화와 관련이 없음이 밝혀졌다. 그 대신에 NaBt는 CCAAT-box를 통한 E-cadherin 유전자의 프로모터 활성을 증가시킴으로써 E-cadherin의 발현을 전사수준에서 촉진하는 것 같다. 이렇게 $\mathrm{NaBt}$ 에 의하여 증가된 E-cadherin은 주로 세포간 접촉면에 위치하면서 $\mathrm{Hep} 3 \mathrm{~B}$ 세포를 더 분화된 형태로 유도하여 $\mathrm{NaBt}$ 의 항암활성이 나타나는 것 같다. 